\title{
STRUCTURAL-AND-SEMANTIC ORGANIZATION OF ANTECEDENT-ANAPHORIC COMPLEX WITH PURPOSE SEMANTICS: COGNITIVE AND FUNCTIONAL ASPECTS
}

\author{
Lyubov V. Voronina
}

Ryazan State Agrotechnological University named after P.A. Kostychev, Ryazan, Russia; Ryazan Branch of the Vladimir Kikot Moscow University of the Ministry of Interior of Russia, Ryazan, Russia

\begin{abstract}
The focus is on the study of the antecedent-anaphoric complex (AAC) as a multipartite method of explicating judgments about the purpose. By way of a continuous sampling procedure, text fragments from verbal shorthand of interviews with political leaders were identified. Having used the methods of introspection, observation and comparison, linguistic modeling and transformation, the author outlined the structural features of AAC with the purpose semantics mainly represented via the proposition-nominal correlation between the initial unit and its referential substitute. Specifics of semantic relations between antecedent and substitute is described; cognitive, linguistic, pragmatic, communicative factors that determine the choice of a complex anaphora as the most optimal model for explicating judgments in an argumentative text type are considered among other prototypical ways of purpose semantics setting. The functions of reference means are analyzed by establishing left-side relationships with the secondary naming elimination of the propositional content within the initial component, right-side relationships in the antecedent-anaphoric complex, as well as in discourse succession. Functional specificity of the models under study is revealed through their cohesion with some subsequent discursive units or intervention of a text unit with the purpose semantics in another antecedent-anaphoric complex structure.

Key words: reference, secondary naming, anaphora, antecedent-anaphoric complex, antecedent, substitute, reference means.

Citation. Voronina L.V. Structural-and-Semantic Organization of Antecedent-Anaphoric Complex with Purpose Semantics: Cognitive and Functional Aspects. Vestnik Volgogradskogo gosudarstvennogo universiteta. Seriya 2. Yazykoznanie [Science Journal of Volgograd State University. Linguistics], 2021, vol. 20, no. 6, pp. 122-133. (in Russian). DOI: https://doi.org/10.15688/jvolsu2.2021.6.11
\end{abstract}

\section{СТРУКТУРНО-СМЫСЛОВАЯ ОРГАНИЗАЦИЯ АНТЕЦЕДЕНТНО-АНАФОРИЧЕСКОГО КОМПЛЕКСА С СЕМАНТИКОЙ ЦЕЛИ: КОГНИТИВНЫЙ И ФУНКЦИОНАЛЬНЫЙ АСПЕКТЫ}

\section{Любовь Валентиновна Воронина}

Рязанский государственный агротехнологический университет им. П.А. Костычева, г. Рязань, Россия; Рязанский филиал Московского университета МВД России им. В.Я. Кикотя, г. Рязань, Россия

Аннотация. В фокусе внимания автора - изучение антецедентно-анафорического комплекса как сложного расчлененного способа экспликации суждений о цели. Материалом для анализа послужили выделенные методом сплошной выборки текстовые фрагменты стенограмм интервью с политическими лидерами, содержащие антецедентно-анафорический комплекс. Посредством интроспекции, наблюдения и сопоставления, лингвистического моделирования и трансформации выявлены особенности струк- 
турной организации антецедентно-анафорического комплекса с семантикой цели на основе пропозитивно-именной корреляции начального компонента и референтного выражения. Установлена специфика смысловых отношений между антецедентом и субститутом, обозначены когнитивные, лингвистические, прагматические, коммуникативные факторы, детерминирующие выбор комплексной анафоры как оптимальной модели экспликации суждений в текст аргументативного типа в ряду типичных способов оформления семантики цели. Проанализирован функционал референтных выражений в аспекте определения как левосторонних отношений - элиминации повторной номинации пропозиционального содержания начального компонента, так и правосторонних связей внутри самого антецедентно-анафорического комплекса, реализующего семантику цели, и в рамках континуума дискурса. Описаны особенности функционирования исследуемых моделей в глубоком контексте при сцеплении их с последующими дискурсивными единицами, а также при интеграции текстовой единицы с семантикой цели в состав иного антецедентно-анафорического комплекса.

Ключевые слова: референция, повторная номинация, анафора, антецедентно-анафорический комплекс, антецедент, субститут, референтное выражение.

Цитирование. Воронина Л. В. Структурно-смысловая организация антецедентно-анафорического комплекса с семантикой цели: когнитивный и функциональный аспекты // Вестник Волгоградского государственного университета. Серия 2, Языкознание. - 2021. - Т. 20, № 6. - С. 122-133. - DOI: https://doi.org/ 10.15688/jvolsu2.2021.6.11

\section{Введение}

Анафорические отношения обсуждаются в лингвистической литературе в большей степени применительно к взаимодействию компонентов внутри сентенции [Падучева, 1990; Уткин, 2003; Шлуинский, 2007], в меньшей - в рамках текста [Валгина, 2003; Воронкова, 2003] и в связи с понятиями референции и повторной номинации [Стросон, 1992; Сёрль, 1992 ].

Понимание референции как «отношения актуализованного, включенного в речь имени или именного выражения (именной группы) к объектам действительности» [Арутюнова, 1992] соответствует основной цели языка - «констатации фактов о предметах, людях и событиях» [Стросон, 1992, с. 55] в аспекте их идентификации (принцип идентификации, по Р.Дж. Сёрлю [Сёрль, 1982, с. 182]) - и применительно к исследуемому антецедентно-анафорическому комплексу (далее - АКК) актуально для интерпретации субститута, или анафора, - «выражения, которое отождествляется с упомянутым ранее» [Прокопеня, 2016, с. 6].

Объектом в данной научной работе выступает антецедентно-анафорический комплекс, реализующий семантику цели в дискурсивных единицах, функционирующих в жанре политического интервью.

Представляя собой пропозитивно-именную корреляцию, ААК может быть квалифицирован как комплексная дискурсивная ана- фора: ее структурная и смысловая сложность обусловлена тем, что антецедент репрезентует «положение дел» в моно- или полиформате, в то время как референтное выражение (с нулевым денотатом) выполняет функцию гиперссылки, направляя внимание реципиента к начальному компоненту; развертывание анафорических отношений в плоскости дискурса, в рамках спонтанного текста, предполагает его членение на составные части (антецедент и субститут) с большей или меньшей степенью независимости и дистантности друг от друга.

В поле нашего зрения - факторы выбора расчлененного способа экспликации суждений о цели, их оформление в соответствии со спецификой языка и прагматическими установками субъекта, коммуникативной организацией смысла высказывания, а также выявление условий развертывания анафора в континууме текста (правосторонние отношения) и его [анафора] разрешения - отсылке к предшествующему фрагменту (левосторонние связи).

\section{Материал и методы}

Материалом исследования послужили опубликованные на официальном сайте президента РФ и других сайтах стенограммы интервью с российскими политическими лидерами. Методом сплошной выборки был сформирован корпус из более чем 1200 единиц, который и был подвергнут многоаспект- 


\section{МАТЕРИАЛЫ И СООБЩЕНИЯ}

ному анализу в соответствии с целями данной научной работы.

Выявление специфики порождения высказываний о цели, особенности их экспликации и функционирования определило ведущие методы исследования - концептуальный анализ, интроспекцию, когнитивное моделирование, дискурс-анализ.

Учет изменения формата связей и ориентации на взаимодействие в out-формате обусловил потенциальное включение дискурсивных единиц с семантикой цели в 3D-анализ: с позиции говорящего - при кодировании суждения в высказывания, выборе формы и способов его выражения; с позиции слушающего - при восприятии, декодировании текста, его понимании и ответной реакции; наконец, в текстовом отношении - его структурной связанности (когезия) и смысловой цельности (когерентность).

\section{Результаты и обсуждение}

\section{ААК с семантикой цели}

\section{как комплексная дискурсивная анафора пропозитивно-именного типа}

Общее представление о том, что анафора - это «отношение между языковыми выражениями (словами или словосочетаниями), состоящее в том, что в смысл одного выражения входит отсылка к другому» [Падучева, 1990, с. 32], ограничивает ее описание, во-первых, рамками предложения, вовторых, исключением из поля зрения корреляции именной группы с пропозитивными выражениями. Однако иной взгляд на проблему повторной (вторичной) номинации, даже в аспекте внутрисентенциальной перспективы, показывает, что на поверхности - «оппозиция предметной / событийной анафорической номинации» [Уткин, 2003], поэтому референтные выражения в логическом ракурсе, как отмечает П.Ф. Стросон, «регулярно используются для референции к конкретному лицу, или единичному предмету, или отдельному событию, или месту, или процессу в ходе обычного высказывания о данном лице, предмете, месте, событии или процессе» [Стросон, 1992, с. 55]. Последнее имеет ключевое значение для нашего исследования, так как референтом целевого высказывания выступают события (см. контекст (1)), процессы (2) или состояния (3), которые эксплицируются в дискурсе посредством текстовых единиц, чаще всего содержащих предикацию (в случае с предложно-падежными конструкциями в свернутом виде):

(1) Мы никак туда [президентские выборы в США] официально не могли залезть. Для этого, понимаете, нужно чувствовать нерв и особенности внутриполитической жизни Соединенных Штатов (ИВП-1);

(2) Очень рассчитываю на то, что ситуация будет развиваться в позитивном ключе. Мы со своей стороны готовы приложить для этого все усилия (ИВП-2);

(3) Я хотел бы сотрудничать с теми людьми, которые стремятся к тому, чтобы Россия стала сильнее, эффективнее, стала конкурентоспособной страной, самодостаточной. Но для этого у людей, о которых мы с Вами говорим, должна быть ясная, четкая программа действий... (ИВП-3).

Использование ААК при выражении целевой семантики следует считать расчлененным способом экспликации цели на том основании, что, в отличие от типичных традиционных конструкций, в рамках простых и сложных предложений сообщение о цели линейно распадается на две части, между которыми устанавливается особый тип отношений.

В первой, независимой от последующей, антецеденте - референтом выступает ситуация, которая репрезентуется в сознании субъекта в форме простых (атрибутивных / экзистенциональных) или сложных (конъюктивных / дизъюнктивных) суждений и эксплицируется в речи в высказываниях, нерелевантных целевым (в них отсутствуют типичные грамматические показатели семантики цели). Они, будучи разными по структурной и семантической сложности, представляют собой: простые предложения с осложнениями (4), сложные предложения (5), фрагменты текстов (6):

(4) Это набор мер, направленных на стимулирование роста мировой экономики, на создание новых рабочих мест. При этом мы исходим из того, что для того, чтобы обеспечить решение этих важнейших задач, нам необходимо решить несколько подзадач (ИВП-4);

(5) Не хватает... понимания того, что чтобы быть успешными, стабильными, процветающими, 
нужно, чтобы все люди, которые на этой территории проживают... чувствовали, что эта территория - их Родина. Для этого они должны почувствовать, что они могут реализовать себя полноценно здесь не хуже, чем на каких-то других территорияХ... (ИВП-5);

(6) В этой связи хотел бы сказать, что наше сотрудничество с Ираном и в ядерной сфере, и в сфере военно-технического сотрудничества не противоречит ни одному международно-правовому акту. Мы не сделали ни одного шага в нарушение каких бы то ни было международных документов, принятых в отношении Ирана. Наша ядерная программа, программа по строительству атомной электростанции в Бушере носит исключительно мирный характер и полностью контролируется инспекторами МАГАТЭ. Там и техника стоит, там постоянно присутствуют наблюдатели МАГАТЭ - нет ни одной претензии к нашей программе по строительству атомной электростанции. Мы и в будущем намерены действовать только таким образом (ИВП-6).

Понимание того, что содержание антецедента - это сообщение о цели, достигается только при наличии второго компонента ААК. Например, в высказывании *Нация должна быть физически и психически здоровой элемент антиципации континуума текста неочевиден.

Второй компонент - анафор, анафорический элемент, субститут [Падучева, 1990], - напротив, обнаруживает свою жесткую структурно-смысловую зависимость от предшествующей части ААК, которая обеспечивается включением специализированных средств повторной номинации (по Н.С. Валгиной) / референтных выражений (по П.Ф. Стросону) / референциальных средств (по А.А. Кибрику). Не обладая собственным семантикой, они становятся формальными показателями, маркерами для интерпретации левосторонних смысловых отношений субститута с антецедентом. Так, вариантами продолжения приведенного выше высказывания (*Нация должна быть физически и психически здоровой) могут быть следующие: * $K$ этому мы приложим все усилия (= ассоциативное изъяснение) / *Потому мы и прикладываем к этому все усилия (= ассоциативное следствие) / *Это наша первоочередная задача (= прямая цель); Для этого мы приложим все усилия (= ассоциативная цель).

Лексико-грамматическая «упаковка» развернутого, полноценного пропозициональ- ного содержания первого компонента в целевую рамку, форму, которую задает референтное выражение, обеспечивает континуум текста в актуальном для говорящего направлении: * Mbl приложим усилия к оздоровлению нациии / * Мы приложим усилия для оздоровления нации / *Здоровье нациии наша задача.

\section{Факторы выбора $А$ АК}

\section{как способа выражсения семантики цели} в политическом дискурсе

Суждения, получая ту или иную материальную оболочку в соответствии с возможностями данного языка, коммуникативными намерениями говорящего и в зависимости от его прагматических установок, с одной стороны, и внешних факторов общения, с другой стороны, выходят за рамки интроспекции, предполагающей исключительную ориентацию на внугренний мир субъекта, его потребности, особенности восприятия действительности, и становятся достоянием внешнего мира, интегрируясь в дискурс - «максимальную языковую единицу» [Кибрик, 2003, с. 11], не всегда экплицитную [Дейк, 2000, с. 43].

Выбор «упаковки» - «способа передачи сообщения» [Чейф, 1982, с. 278] - обусловлен рядом факторов лингвистического, коммуникативного, прагматического и когнитивного порядка.

Так, компактные по объему, семантически выхолощенные, но формирующие необходимую грамматическую рамку $\left(д л я+\mathrm{N}_{2}\right)$, ассоциируемую исключительно с целевой семантикой, референциальные выражения в исследуемых антецедентно-анафорических комплексах меняют модальный статус денотата, перенося его в иную модальную плоскость - интенциональную, и становятся, по нашим данным, самым частотным способом организации анафорических отношений в АКК с семантикой цели [Воронина, 2020].

Теоретически всякая двухкомпонентная синтаксическая конструкция с семантикой цели может быть трансформирована в ААК с большей или меньшей степенью смыслового совпадения. Например, даны две более или менее идентичные ситуации: 1) необходимость развивать экономику страны; 2) необ- 
ходимость развивать экономику страны максимально быстрыми темпами. Обе репрезентуются в сознании субъекта в плоскости потребности, каждая предполагает определенный набор действий, направленных на реализацию задуманного, - готовность сделать все возможное.

Первая ситуация, объективно нейтральная, наиболее вероятно будет эксплицирована типичными грамматическими средствами выражения семантики цели: *Mb сделаем все возможное для развития экономики страны / *Mbl сделаем все возможное, чтобы развивать экономику страны. Вторая содержит оценочный компонент (максимально быстрыми темпами), который потребует своей манифестации и соответствующей выделенности в потоке речи - в начальном компоненте лексическими средствами интерсубъектной модальности необходимости (*Необходимо развивать экономику страны максимально быстрыми темпами) или посредством оценочных лексем (*Наша цель / наша первоочередная задача - развивать экономику страны максимально быстрыми темпами); в субституте - коммуникативно: референциальное средство повторно акцентирует содержание антецедента (для этого) и организует правосторонние связи континуума текста, сообщая о средствах достижения заявленной цели (*Для этого мы сделаем все возможное).

Исследование корпуса политических интервью показало, что выбор расчлененного способа экспликации цели обусловлен актуализацией коннотативного слоя семантики текстовой единицы в субституте (компонент «ресурсы»). Цель также должна представляться субъекту значимой (что подчеркивается лексически): он готов, должен, обязан сделать нечто (все возможное) для достижения поставленных целей / решения заявленных задач:

(7) Я думаю, что помочь им можно, но для этого нужно прежде всего сделать так, чтобы наконец воцарился мир и чтобы абхазы, грузины, осетины могли находиться в нормальном полноценном диалоге. И тогда можно разрешить самые сложные вопросы (ИДМ-1).

Порождение и моделирование суждений, их непосредственная одномоментная экспли- кация в устной форме дискурса осуществляется в рабочей памяти, объем которой незначителен, потому линейно протяженные высказывания неактуальны: как отмечает А.А. Кибрик, дискурс «порождается не как плавный поток, а толчками, квантами» [Кибрик, 2003, с. 22], каждому из них соответствуют клаузы, или «просодические фразы», которые представляют собой «лингвистическое выражение того, что в данный момент находится в... фокусе сознания говорящего» [Чейф, 2008, с. 81]. Следовательно, речь не что иное, как словесный эквивалент следующих друг за другом фокусов сознания. В этой связи членение «антецедент - анафор» не просто конгруэнтно последовательным речевым экспликациям, оно предполагает некий бэкбриджинг - возврат к предшествующей мысли, ее дублирование в новом ракурсе, а затем последующее развитие.

Описанная выше последовательность речевых сигналов, с одной стороны, нарушает принцип их восприятия, которое является «строго линейно упорядоченной, разворачивающейся слева направо» [Бирвиш, 1988, с. 94], с другой - служит подтверждением позиции У. Чейфа о том, что мысли имеют безусловный приоритет над звуками [Чейф, 2008, с. 83], а потому нарушаемая в синтаксических конструкциях с ААК последовательность, на наш взгляд, не мешает восприятию, а, наоборот, обеспечивает максимальное внимание адресата к излагаемой информации.

Очевиден факт ощутимой, по мнению E.P. Даниловой, органичности комплексной анафоры в жанре политического интервью [Данилова, 2016, с. 178]. Данный тип дискурса, предполагающий незамедлительную реакцию респондента на порой неудобные вопросы, стимулирует использование средств, дающих время на размышление. Оптимальными для этого являются расчлененные способы выражения мысли, поскольку они создают дополнительную возможность говорящему изменить направление интерпретации сказанного.

Кроме того, суждения о цели всегда значимы, а потому требуют коммуникативной выделенности - особенно в рамках аргументативного типа изложения, характерного для жанра интервью. Акцентирование цели в та- 
ких конструкциях происходит дважды: сначала в антецеденте выделяется новая значимая информация (комплексная рема), затем включается референциальное средство и выносится в начало анафорического компонента, что способствует актуализации содержания антецедента в сознании субъекта путем отсылки к нему. К тому же корреляция «антецедент анафор» с точки зрения экспрессивности высказывания намного насыщеннее традиционных способов экспликации цели: позиция анафора требует постановки паузы, ударной позиции, особой интонации.

Например, существуют два события встреча лидеров государств и их желание / потребность решить проблему. В речи они эксплицируются в высказывания о цели, оформленные как типичными для цели способами: *Лидеры 8 государств собрались вместе, чтобы решить важнейтие задачи современности, так и расчлененно: *Необходимо решать важнейшие задачи современности. Для этого собрались политические лидеры 8 государств. При этом второй вариант наиболее вероятно будет функционировать в тех жанровых разновидностях дискурса, для которых характерно обоснование (позиции, действий): структуры ААК с семантикой цели и обоснования, говоря словами Я.С. Яскевича, с его «ответом на вопрос “что и как?”» [Яскевич] релевантны (что? - антецедент, $\kappa a \kappa ?-$ анафор). Типичное оформление- с констатацией того или иного события, процесса, состояния - актуально для жанров новостей и аналитической статьи.

\section{Развертывание правосторонних контекстуальных связей $А$ АК с семантикой цели в политическом дискурсе}

Трех аспектов функциональности антецедентно-анафорического комплекса - a) экспликации суждения расчлененным способом в связи с когнитивными обстоятельствами, в соответствии с прагматическими установками субъекта и жанровой спецификой дискурca; б) стремления говорящего элиминировать повторную номинацию пропозиционального плана антецедента в субституте; в) структурной жесткости ААК - отнюдь не достаточно для понимания его функционала в рамках более широкого контекста.

Интеграция синтаксических структур с антецедентно-анафорическим комплексом обеспечивает линейное развертывание континуума текста:

1) в рамках собственно ААК с семантикой цели (субституте);

2) при включении исследуемых ААК в более широкий контекст;

3) при интеграции текстовой единицы с семантикой цели, организованной типичными традиционными для ее выражения языковыми способами, в структуру иного ААК.

При развертывании континуума текста в рамках ААК со значением цели актуализируется прагматический слой семантики высказывания в ситуациях, типичных для целевого контекста:

- акцентации цели как единственно значимой для субъекта:

(8) Но мы готовы оказать содействие и официальным властям Сирии, и здоровой части оппозиции в том, чтобы они нашли между собой какието точки соприкосновения и договорились о политическом будущем своей страны. Именно для этого мы организовали в Москве серию встреч представителей оппозиции и представителей правительства Асада (ИВП-7);

- ситуации непринятия цели:

(9) Может быть, если бы мы занялись этим целенаправленно, мы, наверное, выявили этих людей, если они существуют. Но у нас такой цели нет и задачи (ИВП-3);

- оценки ресурсов с точки зрения их достаточности и предпочтения:

(10) Мы знаем, что и у Китая есть уже существенные достижения. Например, в сфере интернета вещей, в сфере цифровой торговли. Но этого для успешного развития в ближайшей перспективе нам всем - и Китаю, и России - будет совершенно недостаточно (ИВП-8);

(11) Мы... будем бесконечно спорить по проблемам Сирии или по каким-то другим мировым проблемам, их достаточно много, по ближневосточной проблеме начнем дискутировать... Для этоголучше находить другие площадки, другие форумы, их достаточно: ООН, например; Совет Безопасности (ИВП-1). 
В силу того, что субститут обладает коммуникативной и смысловой силой, а также подчеркнутой интонацией завершения, актуальной для ситуаций пояснения, обоснования и т. п., функционирование антецедентноанафорических комплексов с семантикой цели в дискурсе специфично потому, что они, вопервых, выступают своего рода финальными клаузами, то есть завершают тематический фрагмент речевого события:

(12) Россия всегда последовательно выступала в поддержку межкорейского диалога. Мы готовы и впредь прилагать для этого все необходимые усилия (ИДМ-2);

во-вторых, способны вносить добавочную информацию в основную ткань текстовой единицы, служить пояснением, комментарием к ее компоненту (структурно разрывать антецедент):

(13) Я, конечно, очень надеюсь на то, что Администрация Соединенных Штатов Америки вместе со специальными службами, которые для этого созданы, вместе с усилиями компаний, за это отвечающих, все-таки эту проблему решит (ИДМ-3).

Антецедентно-анафорические комплексы с семантикой цели способны интегрироваться в более широкий контекст. Частотными для них выступают контексты обусловленности - причины (13) и следствия (14):

(14) Мы в ближайшие годы не планируем повышать возраст выхода на пенсию. Но не потому, что у нас для этого нет объективных оснований, а потому, что такие решения обязательно требуют очень серьезного обсуждения и общественного согласия (ИДМ-4);

(15) Потому что мы знаем... сотрудники правоохранительных органов... «крышуют» какие-то преступления, для этого преодолевают расстояние в сотни и тысячи километров. И возникает совершенно удивительная ситуация, когда люди, приехавшие абсолютно из другого региона непонятно для чего, занимаются «правоохранительной» деятельностью, а местные правоохранительные структуры, местная милиция об этом даже не знает (ИДМ-5).

Развитие континуума текста при включении текстовой единицы с семантикой цели в состав иного ААК связано с установлением логико-смысловых отношений между компонентами комплекса в нескольких направлениях.

Развертывание континуума по линии «цель» осуществляется в следующих ситуациях: неприятие субъектом целевого события (16), его актуализация (17), (18), оценка (19), (20), расширение позиции субъекта (21):

(16) Я не для того стал Президентом страны, чтобы удовлетворять личные амбиции. Мне это совершенно ни к чему, если интересами России пренебрегают (ИВП-9);

(17) Изначально, когда АТЭС создавался, во главу угла была поставлена цель либерализации мировой экономики. И мы намерены этот вопрос сделать ключевым в ходе обсуждения во Владивостоке (ИВП-10);

(18) Мы ставим перед собой цель развития нашего общества, дальнейшей его демократизации и по этому пути будем двигаться дальше, не собираемся с него сворачивать (ИВП-10);

(19) Сегодня кто-то хочет использовать бойцов «Аль-Каиды» либо людей из других организаций, но с такими же крайними взглядами для достижения своих целей в Сирии. Это очень опасная и недальновидная политика (ИВП-10);

(20) ...Мы понимали, что есть различного рода намерения силой восстановить территориальное единство страны, использовать войска, я думал, что это параноидальный сценарий, который никогда не будет реализован (ИДМ-1);

(21) Вы знаете, что мы на востоке страны сейчас возводим новый космодром как раз для целей народного хозяйства, для гражданских целей. Мне представляется, что Республика Корея могла бы принять участие и в этой работе (ИВП-11).

Функционирование подобных конструкций в политическом дискурсе способствует формированию отношения аудитории к содержанию цели, сообщаемой адресантом. Кроме того, семантика имени в составе референциального средства, направляющего внимание к антецеденту, позволяет оценить масштаб целевого события с позиции говорящего (контекстуальные синонимы вопрос, политика, сценарий).

Развертывание континуума по линии «ресурсы» осуществляется в аспекте их наличия (22), конкретизации (23), условий достижения цели (24):

(22) В основе должны лежать принципы равенства, уважения международного права, недели- 
мости безопасности, неприменения силы или угрозы силой. Сегодня эта задача становится все более актуальной. Ее решению призван способствовать предстоящий саммит Совещания по взаимодействию и мерам доверия в Азии (ИВП-12);

(23) ....Мы продолжим создавать специализированные многофункциональные спортивные объекты, повышать квалификации педагогов по адаптивной физкультуре, чтобы люди с ограниченными возможностями здоровья имели равные возможности для занятий спортом и самореализации. Болышая работа на этом направлении идет в рамках специальных программ «Развитие физической культуры и спорта» и «Доступная среда»(ИВП-13);

(24) Наша задача - восстановить прибрежную среду. И без помощи ученых и специалистов, в первую очередь географической и смежных наук, сделать это будет невозможно (ИВП-14).

Интегрируясь в дискурс, анафора способствует дальнейшему развертыванию текста, обогащению исходной единицы новыми синтаксическими связями и смысловыми отношениями.

\section{Выводы}

Эксплицированная цель по своей природе декларативна. Ее манифестация в политическом дискурсе - вопрос не столько речевых стратегий, сколько дипломатических уловок.

Обстоятельства субъективного порядка формируют ситуации намеренной декларации цели в ходе спонтанной речи, обусловливают ее принятие или непринятие, интерпретацию, оценку субъектом. В речевом потоке такие высказывания редко функционируют сами по себе. Они вплетаются в структурно-семантическую ткань дискурсивной единицы, погружаются в глубокий контекст, сообщающий о причинах действий, релевантности желаемого результата реальному, условиях достижения цели и т. д. Следовательно, выражение целевой семантики осуществляется за рамками конкретной структуры, рассредоточивается по тексту, актуализируя при этом разные аспекты целенаправленного действия или субъекта целеполагания. Появляется объективная необходимость в повторной номинации целевого события, которая реализуется посредством референтных выражений, самые частотные из которых - реду- цированные именные группы с анафорическими местоимениями.

Квалификация АКК как расчлененного способа экспликации целевой семантики детерминирована особенностями организации комплекса. Это двухкомпонентные структуры, в основе которых - корреляция выражений с пропозициональным значением и референциальных средств, обеспечивающих развертывание право- и левосторонних связей субститута в дискурсе на разных уровнях: как в рамках собственно синтаксической конструкции, в состав которой включен антецедентноанафорический комплекс, так и в более широком контексте - при его взаимодействии с другими синтаксическими структурами, в том числе интеграции в конструкции, включающие иные ААК, с последующим развертыванием континуума в направлениях «цель» и «ресурсы».

Выбор, осуществляемый говорящим в процессе спонтанной речи в пользу исследуемых конструкций, не только когнитивно обусловлен, но и определяется действием ряда факторов - лингвистических, коммуникативных, прагматических.

Двухчастная структура («антецедент субститут») позволяет говорящему дважды фокусировать внимание адресата («фокус сознания») на одном и том же событии, но не дублировать его, а высвечивать в разных ракурсах: сначала как утверждение его наличия (денотат), а затем как устремление к нему (референция к цели). Этот факт во многом определяет коммуникативную организацию смысла текстовой единицы, предполагающую подчеркнутую выделенность АКК в потоке речи (коммуникативный фактор), а также однозначный выбор грамматической формы референциального средства (для этого), ассоциируемой с целевой семантикой (лингвистический фактор).

Потенциальная актуализация коннотативного слоя значения текстовой единицы с АКК в обоих компонентах семантической структуры цели вкупе с рядом просодических средств акцентации смысла образуют комплекс средств, обеспечивающих успешную реализацию установок адресанта на убедительность, экспрессивность, оценочность коммуникации (прагматика), что в свою очередь 


\section{МАТЕРИАЛЫ И СООБЩЕНИЯ}

позволяет нам считать ААК с семантикой цели наиболее оптимальным способом из ряда альтернативных, типичных способов выражения целевой семантики с точки зрения жанровой обусловленности и аргументативного формата экспликации суждений.

\section{СПИСОК ЛИТЕРАТУРЫ}

Арутюнова Н. Д., 1992. Лингвистические проблемы референции // Новое в зарубежной лингвистике. Вып. 13. Логика и лингвистика (проблемы референции). М. : Радуга. С. 5-41.

Бирвиш М., 1988. Насколько линейно упорядоченной является языковая обработка // Новое в зарубежной лингвистике. Вып. 23. Когнитивные аспекты языка. М. : Прогресс. С. 93-152.

Валгина Н. С., 2003. Теория текста. М. : Логос. 193 с.

Дейк Т. А. ван, 2000. Язык. Познание. Коммуникация. Благовещенск : БГК им. И.А. Бодуэна де Куртенэ. 308 c.

Воронина Л. В., 2020. Вопросы релевантности референта и референтного выражения антецедентно-анафорического комплекса, реализующего семантику цели в политическом дискурсе // Вестник Московского государственного областного университета. Серия: Филология. № 5. С. 16-25.

Воронкова А. В., 2003. Стратегии обработки дискурсивной анафоры пропозитивно-именного типа : автореф. дис. ... канд. филол. наук. Орел. 28 c.

Данилова Е. Р., 2016. Комплексная анафора в риторико-стилистическом аспекте жанра политической речи // Историческая и социально-образовательная мысль. Т. 8, № 3, ч. 1. С. 178-183.

Кибрик А. А., 2003. Анализ дискурса в когнитивной перспективе : дис. ... д-ра филол. наук. М. 89 с.

Падучева Е. В., 1990. Анафорическое отношение // Лингвистический энциклопедический словарь / гл. ред. В. Н. Ярцева. М. : Сов. энцикл., 1990. C. 32.

Прокопеня В. К., 2016. Механизмы анафоры при речепорождении и речепонимании: экспериментальное исследование на материале русского языка : дис. ... канд. филол. наук. СПб. $276 \mathrm{c}$.

Сёрль Р. Дж., 1992. Референция как речевой акт // Новое в зарубежной лингвистике. Вып. 13. Логика и лингвистика (проблемы референции). М. : Радуга. С. 179-202.

Стросон П. Ф., 1992. О референции // Новое в зарубежной лингвистике. Вып. 13. Логика и лингвистика (проблемы референции). М. : Радуга. C. $55-87$.
Уткин Е. Б., 2003. Семантические особенности анафорических отношений в относительно-распространительных сложноподчиненных предложениях // Русская сопоставительная словесность: взгляд молодых. URL: http://www.ksu.ru/f10/ publications/2003/rsf_molodye_19.htm (дата обращения: 20.01.2021).

Чейф У., 1982. Данное, контрастивность, определенность, подлежащее, топики и точка зрения // Новое в зарубежной лингвистике. Вып. 11. Современные синтаксические теории в американской лингвистике. М. : Прогресс. С. 277-316.

Чейф У., 2008. Роль интроспекции, наблюдения и эксперимента в понимании мышления // Вопросы языкознания. № 4. С. 78-88.

Шлуинский А. Б., 2007. Анафорические отношения в сложном предложении. URL: https://ilingran.ru/Shluinsky/ashl/Anaforicheskie Otnoshenija_2007 (дата обращения: 04.06.2020).

Яскевич Я. С. Обоснование // Гуманитарная энциклопедия. Концепты научного дискурса. URL: https://gtmarket.ru/concepts/7097 (дата обращения: 04.06.2020).

\section{ИСТОчНИКИ}

ИВП-1 - Интервью В.В. Путина холдингу Bloomberg. 01.09.2016. URL: http://www.kremlin. ru/events/president/news/52830 (дата обращения: 21.06.2020).

ИВП-2 - Интервью В.В. Путина телеканалу ORF. 04.06.2020. URL: http://www.kremlin.ru/events/ president/news/57675 (дата обращения: 21.06.2020).

ИВП-3 - Интервью В.В. Путина телеканалу NBC. 02.03.2018. URL: http://www.kremlin.ru/events/ president/news/57027 (дата обращения: 22.06.2020).

ИВП-4 - Интервью В.В. Путина Первому каналу и агентству Ассошиэйтед Пресс. 01.09.2013. URL: http://www.kremlin.ru/events/president/ news/19143 (дата обращения: 21.06.2020).

ИВП-5 - Интервью В.В. Путина телеканалу ARD. 17.11.2014. URL: http://www.kremlin.ru/events/ president/news/47029 (дата обращения: 22.06.2020).

ИВП-6 - Интервью В.В. Путина телеканалу «АльДжазира». 10.02.2007. URL: http://www.kremlin. ru/events/president/transcripts/24035 (дата обращения: 03.07.2020).

ИВП-7 - Интервью В.В. Путина американскому журналисту Чарли Роурзу для телеканалов CBS и PBS. 29.09.2015. URL: http://www.kremlin. ru/events/president/news/50380 (дата обращения: 03.07.2020). 
ИВП-8 - Интервью В.В. Путина Медиакорпорации Китая. 06.06.2018. URL: http://www.kremlin.ru/ events/president/news/57684 (дата обращения: 03.07.2020).

ИВП-9 - Интервью В.В. Путина ТАСС. 13.11.2014. URL: http:/www.kremlin.ru/events/president/ news/47009 (дата обращения: 03.07.2020).

ИВП-10 - Интервью В.В. Путина телеканалу Russia Today. 06.09.2012. URL: http://www.kremlin.ru/ events/president/news/16393 (дата обращения: 04.07.2020).

ИВП-11 - Интервью В.В. Путина южнокорейской телерадиокомпании KBS. 12.11.2013. URL: http:/www.kremlin.ru/events/president/news/ 19603 (дата обращения: 04.07.2020).

ИВП-12 - Интервью В.В. Путина ведущим СМИ Китая. 19.05.2014. URL: http://www.kremlin.ru/ events/president/news/21031 (дата обращения: 04.07.2020).

ИВП-13 - Интервью В.В. Путина российским и иностранным СМИ. 06.03.2014. URL: http://www. kremlin.ru/events/president/news/20080 (дата обращения: 04.07.2020).

ИВП-14 - Интервью В.В. Путина журналу «Вокруг света». 23.09.2014. URL: http://www.kremlin.ru/ events/president/news/46660 (дата обращения: 04.07.2020).

ИДМ-1 - Интервью Д.А. Медведева телеканалам «Russia Today», «Первый информационный кавказский» и радиостанции «Эхо Москвы». 05.08.2011. URL: https://echo.msk.ru/programs/ beseda/799478-echo/ (дата обращения: 07.07.2020).

ИДМ-2 - Интервью Д.А. Медведева корейским СМИ. 09.11.2010. URL: http://www.kremlin.ru/ events/president/news/9467 (дата обращения: 07.07.2020).

ИДМ-3 - Интервью Д.А. Медведева американской газете «Уолл-стрит джорнэл». 08.07.2010. URL: http:/www.kremlin.ru/events/president/news/ 8082 (дата обращения: 07.07.2020).

ИДМ-4 - Ответы Д.А. Медведева на вопросы журналистов «Российской газеты». 11.10.2010. URL: http://www.kremlin.ru/events/president/ transcripts/9486 (дата обращения: 16.08.2020).

ИДМ-5 - Встреча Д.А. Медведева с журналистами «Российской газеты». 08.11.2010. URL: http:// www.kremlin.ru/events/president/news/9457 (дата обращения: 16.08.2020).

\section{REFERENCES}

Arutyunova N.D., 1992. Lingvisticheskie problemy referentsii [Linguistic Problems of Reference]. Novoe v zarubezhnoy lingvistike Vyp. 13. Logika i lingvistika (problemy referentsii) [New in Foreign Linguistics. Iss. 13. Logic and Linguistics (Problems of Reference)]. Moscow, Raduga Publ., pp. 5-41.

Birvish M., 1988. Naskolko lineyno uporyadochennoy yavlyaetsya yazykovaya obrabotka [How Linearly Ordered is Language Processing]. Novoe v zarubezhnoy lingvistike. Vyp. 23. Kognitivnye aspekty yazyka [New in Foreign Linguistics. Iss. 23. Cognitive Aspects of Language]. Moscow, Progress Publ., pp. 93-152.

Valgina N.S., 2003. Teoriya teksta [Text Theory]. Moscow, Logos Publ. 193 p.

Dejk T.A. van, 2000. Yazyk. Poznanie. Kommunikatsiya [Language. Cognition. Communication]. Blagoveshchensk, BGK im. I.A. Boduena de Kurtene. 308 p.

Voronina L.V., 2020. Voprosy relevantnosti referenta i referentnogo vyrazheniya antetsedentnoanaforicheskogo kompleksa, realizuyushchego semantiku tseli $\mathrm{v}$ politicheskom diskurse [Relevance of the Reference and Referential Mean Within the Antecedent-Anaphoric Complex with Purpose Semantics in Political Discourse]. Vestnik Moskovskogo gosudarstvennogo oblastnogo universiteta. Seriya: Filologiya [Bulletin of the MSR University. Series: Russian Philology], no. 5 , pp. $16-25$.

Voronkova A.V., 2003. Strategii obrabotki diskursivnoy anafory propozitivno-imennogo tipa: avtoref. dis. ... kand. filol. nauk [Strategies for Processing the Discursive Anaphora of the Propositive-Nominal Type. Cand. philol. sci. abs. diss.]. Orel. 28 p.

Danilova E.R., 2016. Kompleksnaya anafora v ritorikostilisticheskom aspekte zhanra politicheskoy rechi [Complex Anaphora in the Rhetorical and Stylistic Aspect of the Genre of Political Speech]. Istoricheskaya i sotsialno-obrazovatelnaya mysl [Historical and Social-Educational Idea], vol. 8, no. 3, part 1, pp. 178-183.

Kibrik A.A., 2003. Analiz diskursa v kognitivnoy perspektive: dis. ... d-ra filol. nauk [Discourse Analysis from a Cognitive Perspective. Dr. philol. sci. diss.]. Moscow. 89 p.

Paducheva E.V., 1990. Anaforicheskoye otnosheniye [Anaphoric Relationship]. Yartseva V.N., ed. Lingvisticheskiy entsiklopedicheskiy slovar [Linguistic Encyclopedic Dictionary]. Moscow, Sovetskaya enciklopediya Publ., p. 32.

Prokopenya V.K., 2016. Mekhanizmy anafory pri recheporozhdenii $i$ recheponimanii: eksperimentalnoye issledovaniye na materiale russkogo yazyka: dis. ... kand. filol. nauk [The Mechanisms of Anaphora in Speech Production and Comprehension: An Experimental Study Based on the Russian Language. Cand. philol. sci. diss.]. Saint Petersburg. 276 p. 
Sjorl R.Dzh., 1992. Referentsiya kak rechevoy akt [Reference As a Speech Act]. Novoe $v$ zarubezhnoy lingvistike. Vyp. 13. Logika $i$ lingvistika (problemy referencii) [New in Foreign Linguistics. Iss. 13. Logic and Linguistics (Problems of Reference)]. Moscow, Raduga Publ., pp. 179-202.

Stroson P.F., 1992. O referentsii [On Reference]. Novoe $v$ zarubezhnoy lingvistike. Vyp. XIII: Logika $i$ lingvistika (problemy referentsii) [New in Foreign Linguistics. Iss. 13. Logic and Linguistics (Problems of Reference)]. Moscow, Raduga Publ., pp. 55-87.

Utkin E.B., 2003. Semanticheskie osobennosti anaforicheskikh otnosheniy $\mathrm{v}$ otnositelnorasprostranitelnykh slozhnopodchinennykh predlozheniyakh [Semantic Features of Anaphoric Relations in Relatively Proliferative Complex Sentences]. Russkaya sopostavitel'naya slovesnost': vzglyad molodykh. URL: http:// www.ksu.ru/f10/publications/2003/rsf molodye 19.htm (accessed 20 January 2021).

ChejfU., 1982. Dannoe, kontrastivnost, opredelennost, podlezhashchee, topiki i tochka zreniya [Givenness, Contrastiveness, Definiteness, Subjects, Topics, and Point of View]. Novoe $v$ zarubezhnoy lingvistike. Vyp. 11. Sovremennye sintaksicheskie teorii $v$ amerikanskoy lingvistike [New in Foreign Linguistics. Iss. 11. Contemporary Syntactic Theories in American Linguistics]. Moscow, Progress Publ, pp. 277-316.

Chejf U., 2008. Rol introspektsii, nablyudeniya i eksperimenta v ponimanii myshleniya [The Roles of Introspection, Observation, and Experimentation in Understanding the Mind]. Voprosy yazykoznaniya [Topics in the Study of Language], no. 4, pp. 78-88.

Shluinskiy A.B., 2007. Anaforicheskie otnosheniya v slozhnom predlozhenii [Anaphoric Relations in a Complex Sentence]. URL: https://iling-ran.ru/ Shluinsky/ashl/AnaforicheskieOtnoshenija_ 2007 (accessed 4 June 2020).

Yaskevich Ya.S. Obosnovanie [Justification]. Gumanitarnaya entsiklopediya. Kontsepty nauchnogo diskursa [Humanitarian Encyclopedia. Scientific Discourse Concepts]. URL: https:// gtmarket.ru/concepts/7097 (accessed 4 June 2020).

\section{SOURCES}

Intervyu V.V. Putina holdingu Bloomberg. 01.09.2016 [Vladimir Putin's Interview to Media Company Bloomberg. September 1, 2016]. URL: http:// www.kremlin.ru/events/president/news/52830 (accessed 21 June 2020).
Intervyu V.V. Putina telekanalu ORF. 04.06.2020 [Vladimir Putin's Interview to ORF TV Channel. June 4, 2020]. URL: http://www.kremlin.ru/ events/president/news/57675 (accessed 21 June 2020).

Intervyu V.V. Putina telekanalu NBC. 02.03.2018 [Vladimir Putin's Interview to NBC TV Channel. March 2, 2018]. URL: http://www.kremlin.ru/events/ president/news/57027 (accessed 22 June 2020).

Intervyu V.V. Putina Pervomu kanalu $i$ agentstvu Assoshieyted Press. 01.09.2013 [Vladimir Putin's Interview to Channel One and the Associated Press Agency. September 1, 2013]. URL: http:// www.kremlin.ru/events/president/news/19143 (accessed 21 June 2020).

Intervyu V.V. Putina telekanalu ARD. 17.11.2014 [Vladimir Putin's Interview to ARD TV Channel. November 17, 2014]. URL: http://www.kremlin.ru/ events/president/news/47029 (accessed 22 June 2020).

Intervyu V.V. Putina telekanalu «Al'-Dzhazira». 10.02.2007 [Vladimir Putin's Interview to AlJazeera TV Channel. February 10, 2007]. URL: http://www.kremlin.ru/events/president/ transcripts/24035 (accessed 3 July 2020).

Intervyu V.V. Putina amerikanskomu zhurnalistu Charli Rourzu dlya telekanalov CBS i PBS. 29.09.2015 [Vladimir Putin's Interview to American Journalist Charlie Rose for CBS and PBS TV Channels]. URL: http:/www.kremlin.ru/events/president/news/ 50380 (accessed 3 July 2020).

Intervyu V.V. Putina Mediakorporatsii Kitaya. 06.06.2018 [Vladimir Putin's Interview to Media Corporation of China. June 6, 2018]. URL: http:// www.kremlin.ru/events/president/news/57684 (accessed 3 July 2020).

Intervyu V.V.Putina TASS. 13.11.2014 [Vladimir Putin's Interview to TASS. November 13, 2014]. URL: http:/www.kremlin.ru/events/president/news/ 47009 (accessed 3 July 2020).

Intervyu V.V. Putina telekanalu Russia Today. 06.09.2012 [Vladimir Putin's Interview to Russia Today TV Channel. September 6, 2012]. URL: http://www.kremlin.ru/events/president/news/ 16393 (accessed 4 July 2020).

Intervyu V.V. Putina yuzhnokoreyskoy teleradiokompanii KBS. 12.11.2013 [Vladimir Putin's Interview to the South Korean Television and Radio Company KBS. November 12, 2013]. URL: http://www.kremlin.ru/events/president/ news/19603 (accessed 4 July 2020).

Intervyu V.V. Putina vedushchim SMI Kitaya. 19.05.2014 [Vladimir Putin's Interview to China's Leading Media Companies. May 19, 2014]. URL: http:/www.kremlin.ru/events/president/news/ 21031 (accessed 4 July 2020). 
Intervyu V.V. Putina rossiyskim i inostrannym SMI. 06.03.2014 [Vladimir Putin's Interview to Russian and Foreign Media. March 6, 2014]. URL: http://www.kremlin.ru/events/president/ news/20080 (accessed 4 July 2020).

Intervyu V.V. Putina zhurnalu "Vokrug sveta». 23.09.2014 [Vladimir Putin's Interview to Magazine "Vokrug Sveta". September 23, 2014]. URL: http://www.kremlin.ru/events/president/ news/46660 (accessed 4 July 2020).

Intervyu D.A. Medvedeva telekanalam «Russia Today», "Pervyy informatsionnyy kavkazskiy» $i$ radiostantsii "Ekho Moskvy». 05.08.2011 [Dmitriy Medvedev's Interview to "Russia Today", "Pervyj informacionnyj kavkazskij” TV Channels, and "Ekho Moskvy" Radio Station. August 5, 2011]. URL: https://echo.msk.ru/programs/beseda/ 799478-echo (accessed 7 July 2020).

Intervyu D.A. Medvedeva koreyskim SMI. 09.11.2010

[Dmitriy Medvedev's Interview to South Korean
Media. November 9, 2010]. URL: http:// www.kremlin.ru/events/president/news/9467 (accessed 7 July 2020).

Intervyu D.A. Medvedeva amerikanskoy gazete «Uoll-strit dzhornel». 08.07.2010 [Dmitriy Medvedev's Interview to the Wall Street Journal. July 8, 2010]. URL: http://www.kremlin.ru/events/ president $/$ news $/ 8082$ (accessed 7 July 2020).

Otvety D.A. Medvedeva na voprosy zhurnalistov "Rossiyskoy gazety». 11.10.2010 [Dmitriy Medvedev's Answers to "Rossiyskaya Gazeta" Journalists. October 11, 2010]. URL: http:// www.kremlin.ru/events/president/transcripts/ 9486 (accessed 16 August 2020).

Vstrecha D.A. Medvedeva s zhurnalistami "Rossiyskoy gazety». 08.11.2010 [Dmitriy Medvedev's Meeting with "Rossiyskaya Gazeta" Journalists. Novermber 8, 2010]. URL: http://www.kremlin.ru/events/president/news/ 9457 (accessed 16 August 2020).

\section{Information About the Author}

Lyubov V. Voronina, Candidate of Sciences (Philology), Associate Professor, Department of Humanities, Ryazan State Agrotechnological University named after P.A. Kostychev, Kostycheva St, 1, 390044 Ryazan, Russia; Associate Professor, Department of Social and Humanitarian Disciplines, Ryazan Branch of the Vladimir Kikot Moscow University of the Ministry of Interior of Russia, 1-ya Krasnaya St, 18, 390043 Ryazan, Russia, lv-voronina@rambler.ru, https://orcid.org/0000-0002-4333-6685

\section{Информация об авторе}

Любовь Валентиновна Воронина, кандидат филологических наук, доцент кафедры гуманитарных дисциплин, Рязанский государственный агротехнологический университет им. П.А. Костычева, ул. Костычева, 1, 390044 г. Рязань, Россия; доцент кафедры социально-гуманитарных дисциплин, Рязанский филиал Московского университета МВД России им. В.Я. Кикотя, ул. 1-я Красная, 18, 390043 г. Рязань, Россия, lv-voronina@rambler.ru, https://orcid.org/0000-0002-4333-6685 